\title{
Meetings: For Almost All of Our Lives
}

\section{Boris Gurevich}

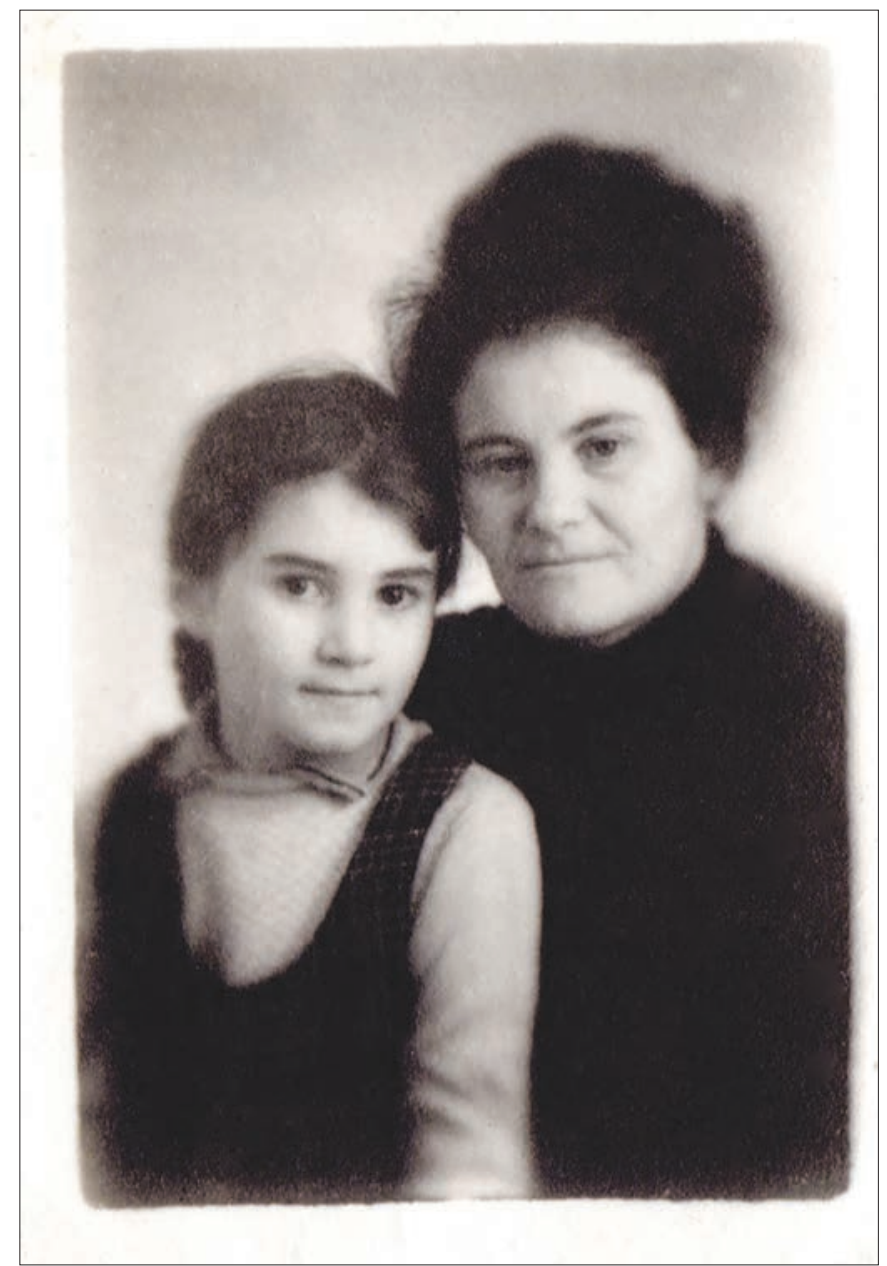

Ratner with her daughter Anna, 1971.

Boris Gurevich is a professor of mathematics at Lomonosov Moscow State University. His email address is gurevich@mech.math.msu.su.

For permission to reprint this article, please contact: reprint -permission@ams.org.

DOI: http://dx.doi.org/10.1090/noti1831

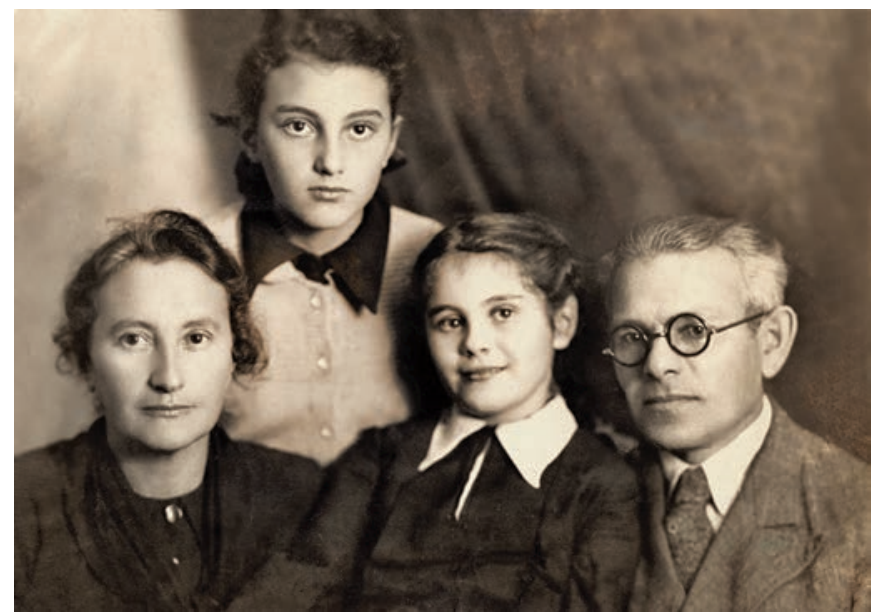

Ratner with her family, 1947 (left to right): mother Ksia, sister Yulia, Marina, and father Yehoshua.

I cannot claim that I have been Marina's close friend from our very first meeting. But I believe at some moment this became so. Our meetings lasted for many years, with frequency dependent on circumstances of our lives and on political events as well. I am going to remember several of these meetings in the hope that my story will shed additional light on this remarkable character.

I got to know Marina when we were about seven years old and went to the same musical school for children. By coincidence we had the same piano teacher, whose name was Anna Ratner. In one or two years I moved to another musical school, closer to my home, and we lost one another for several years.

Our next meeting occurred at the Mechanics and Mathematics Department of Moscow State University, where we entered simultaneously and quite independently. I happened to meet Marina at one of the first lectures and recognized her almost immediately, strange though it may seem. That is why when in several days our very sociable 


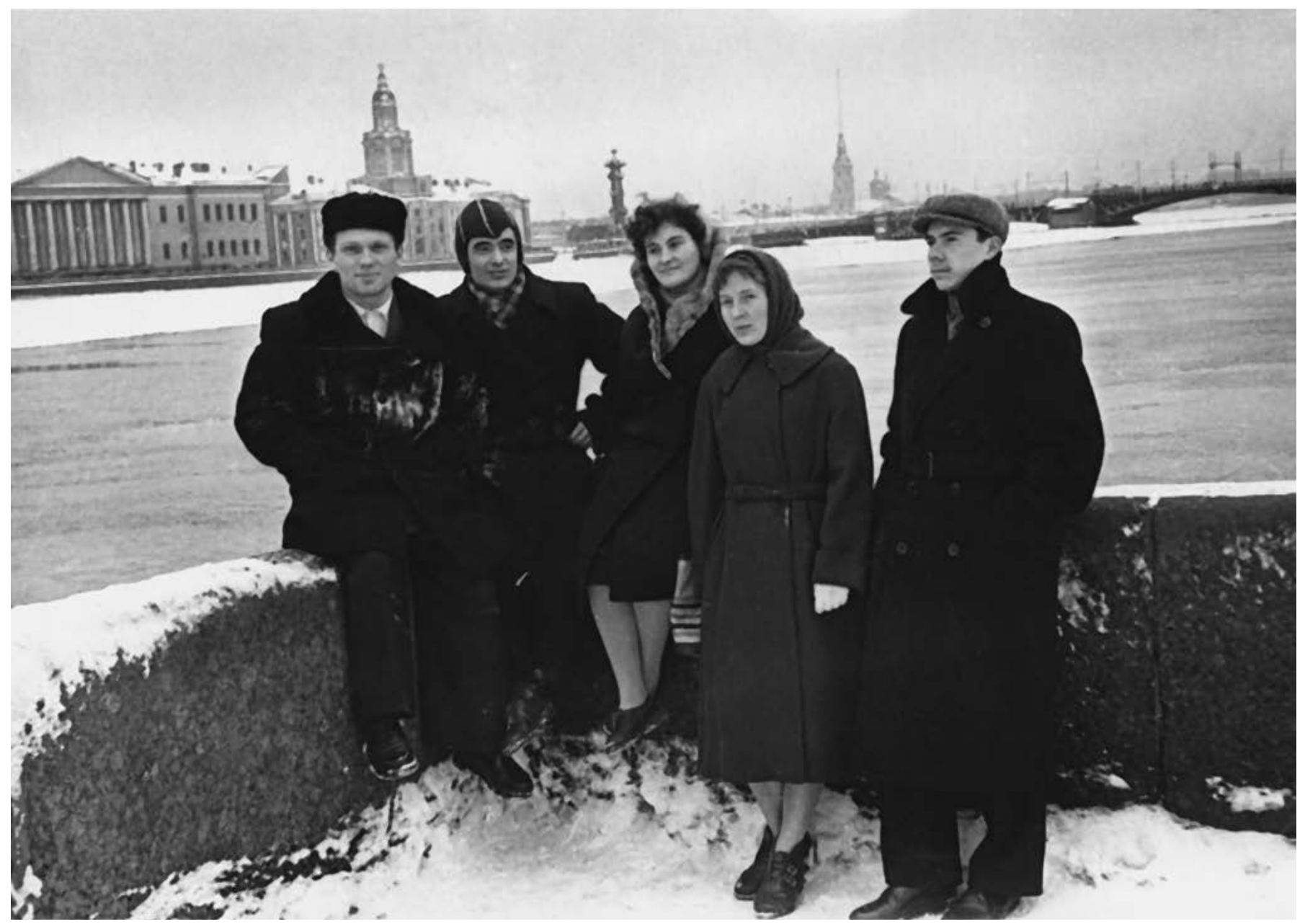

Visiting Leningrad with fellow students - (left to right) Ilya Mindilin, Vener Galin, Lena Odnorobova (orVera Steniushkina), Slava Perlov) -from Moscow, circa 1961.

fellow student tried to introduce me to her, this sounded funny for both of us.

During the first two years we were in different groups and met only at common lectures. But in our third year, everybody had to choose a specialization. And again, we made the same choice, which was probability, and got into the same group.

At that time the probability and statistics subdivision of the department was headed by A. N. Kolmogorov, and almost all who worked there were his former students. Kolmogorov was very active in various directions; in a few years he included Marina in a small, young team involved in his study of statistical laws in language. But her first supervisor was R. L. Dobrushin, who, as I know, liked very much her master's thesis in information theory.

Upon graduating from the university, Marina was for some time working at Kolmogorov's boarding school, a high school for gifted children from all over the country founded by Kolmogorov and later named after him. She also took part in the preparation of the principal works of Claude Shannon for publication in Russian.
About that time she married a student from our course, and I met her not too often. But in 1965 she came back to the university as a graduate student under the supervision of Y. G. Sinai, and our meetings became regular again because we both attended seminars on ergodic theory.

Once we examined an undergraduate. I began with a question, then Marina entered and I went out for some time, while she continued. When I came back, I was not pleased that she finished too fast. But later I decided that she was right: first, this student was Lenya Bunimovich, and second, Marina was very thorough in everything. Once, already in Berkeley, she observed that in one of her papers, it was written "weak convergence" instead of "weak* convergence," and she asked me to insert the asterisk by pen each time I was at a library where a journal with the paper was accessible. She told me, "I am a perfectionist," and this was the truth.

She published several papers and defended her PhD thesis on geodesic flows in 1969. Thereafter she was teaching at one of the technical universities in Moscow, but not for very long, because she applied for emigration to Israel. 


\section{MEMORIAL TRIBUTE}

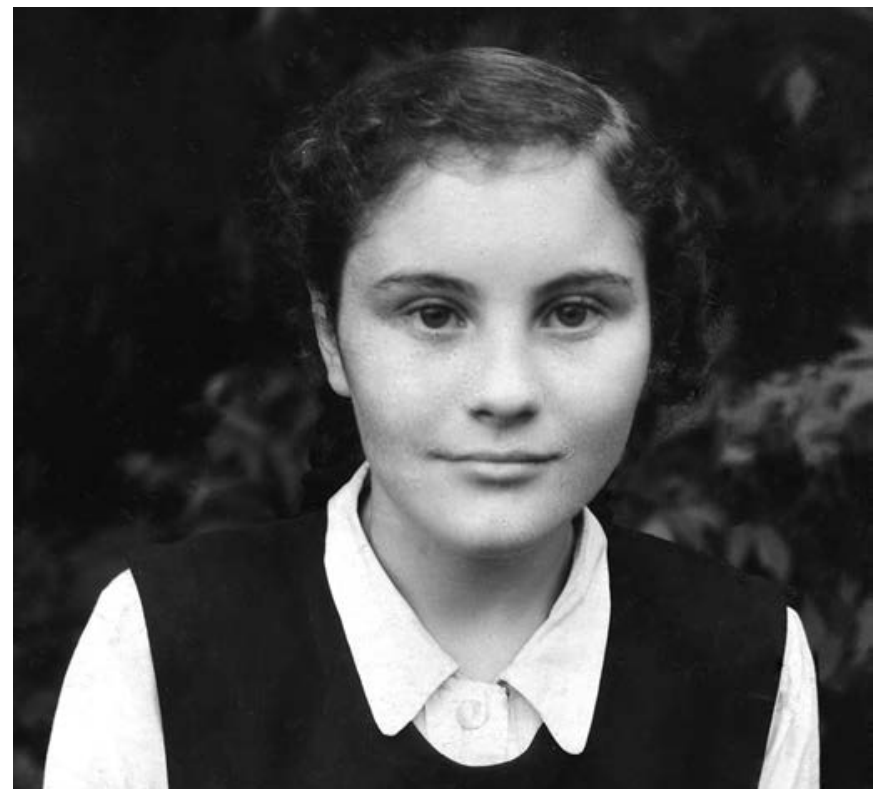

As a girl of twelve, 1950 .

Honestly speaking, I initially considered her intention reckless: I knew that she was going alone, with a small daughter, without language and having no relatives there.

But I had underestimated Marina: she overcame difficulties, which were indeed considerable, and in 1971 she was already working at the Hebrew University. At the time, the Soviet Union had no diplomatic relations with Israel and postal services were unreliable. Of fragmentary information from Marina I remember that in the fall of 1973, the university professors were asked to write their lectures down in order that the students, turned into soldiers for a while, could read them at the front.

When Marina moved to Berkeley, I used a possibility to hear something of her from J. Feldman, whom I met in 1977 in Warsaw at a conference on ergodic theory.

Only when Gorbachev came to power did mutual visits become possible. Marina came to Moscow more than one time in the 1990s and early 2000s. Once she left for a few days for Minsk, where a mathematical conference was conducted. Being aware of food shortage in Moscow at the time, she bought in Minsk, on her own initiative, some cheese for a small child of our friend. I appreciated her solicitous concern for her friends once again when I visited her at Berkeley in the late 1990s.

As far as I know, she came to Moscow for the last time in June of 2003 to the conference devoted to Kolmogorov's centennial, where she was an invited speaker and met many old friends.

I saw Marina for the last time in May 2014 in Oslo, where we were invited by Sinai, our common teacher, as his guests as he was awarded the Abel Prize. We walked through the city in full lilac bloom and followed Sinai, visiting the town of Stawanger for one day, where we took, together with a few friends, an excursion along a fjord; Marina took a number of snapshots there.

She was always worried about the health of others. Throughout several years she insisted that I should regularly inform her of my state of health (results of tests, etc.). Answering my questions about her own health, she would always insist that she was splendidly sound. I have kept her last message of July 1, 2017, in which she wrote about her problems, but hoped that the treatment would eventually help. I also thought so.

\section{Credits}

All photos are courtesy of Anna Ratner. 